\title{
Valor nutritivo de silagens de capim-marandu submetidas aos efeitos de umidade, inoculação bacteriana e estação do ano ${ }^{1}$
}

\section{José Leonardo Ribeiro², Luiz Gustavo Nussio ${ }^{3}$, Gerson Barreto Mourão ${ }^{4}$, Lucas José Mari², Maity Zopollatto ${ }^{2}$, Solidete de Fátima Paziani ${ }^{5}$}

\author{
1 Pesquisa financiada pela FAPESP. \\ 2 Programa de Pós-graduação em Ciência Animal e Pastagens, USP/ESALQ. \\ ${ }^{3}$ Departamento de Zootecnia da USP/ESALQ. \\ ${ }^{4}$ Departamento de Ciências Exatas da USP/ESALQ. \\ ${ }^{5}$ Apta Centro Norte/SAA.
}

RESUMO - O estudo foi realizado para avaliar o efeito da estação do ano, do teor de matéria seca (MS) e da inoculação bacteriana sobre o valor nutritivo de silagens de Brachiaria brizantha cv. Marandu. O delineamento experimental foi o inteiramente casualizado, disposto em arranjo fatorial $(2 \times 3 \times 3)$, com duas estações do ano (verão e inverno), três teores de MS (com ou sem emurchecimento ou adição de polpa cítrica peletizada, PCP) e ausência ou presença de inoculante (Lactobacillus plantarum ou Lactobacillus buchneri), perfazendo 18 tratamentos, cada um com quatro repetições. As silagens foram confeccionadas em baldes de plástico de 20 L. Após 90 dias do fechamento, os silos foram abertos para as avaliações. O emurchecimento elevou os teores de matéria seca (MS), fibra em detergente neutro (FDN) e lignina (LIG) em ambas as estações, porém não alterou o coeficiente de digestibilidade verdadeira in vitro da MS (DVIVMS) das silagens. A adição de PCP aumentou os teores de proteína bruta (PB) e carboidratos solúveis (CHO) e reduziu os teores de FDN, o que resultou em silagens com maior DVIVMS em ambas as estações. A inoculação não alterou a fração fibrosa e não aumentou a DVIVMS das silagens. As silagens de verão apresentaram maiores teores de PB e menores constituintes da parede celular, com exceção da hemicelulose (HEMI), o que resultou no maior coeficiente médio de DVIVMS dessas silagens. O baixo valor nutritivo das silagens de inverno contraria os resultados descritos na literatura, principalmente em virtude da maior idade de rebrotação do capim-marandu nesta estação. Desta forma, silagens de verão podem ser recomendadas como volumoso suplementar, principalmente quando acrescidas de PCP.

Palavras-chave: digestibilidade, emurchecimento, Lactobacillus buchneri, Lactobacillus plantarum, polpa cítrica peletizada

\section{Nutritive value of palisadegrass silages affected by year season, dry matter level and bacterial inoculant}

\footnotetext{
ABSTRACT - The objectives of this work were to evaluate the effect of year season, dry matter concentration (DM), and bacterial inoculation on the nutritive value of palisadegrass silages. The trial was carried out in a complete randomized experimental design with four replications, in a factorial arrangement $(2 \times 3 \times 3)$ : two year seasons (summer and winter), three dry matter levels (with or without wilting or added with dried citrus pulp), and without microbial additive or with Lactobacillus plantarum or Lactobacillus buchneri, totalizing 18 treatments. Silages were stored in 20 L plastic buckets. After 90-d of fermentation, the silos were opened and the silages were evaluated. Wilting increased DM, neutral detergent fiber (NDF), and lignin (LIG), in both year seasons, and did not change in vitro true dry matter digestibility (IVTDMD). Addition of citrus pulp increased crude protein (CP) concentration and water soluble carbohydrates (WSC) and decreased the NDF concentration. As a result, this additive increased the IVTDMD in both year seasons. The use of microbial inoculants did not change fiber fractions and did not increase the IVTDMD in the silages. Summer-silages had higher CP level and lower cell wall concentrations, except for HEM, resulting in higher IVTDMD. The low nutritive value obtained for the winter silages was not in agreement with the literature, mainly due to the greater regrowth age of palisadegrass in this season. As a result, the overall analysis pointed out that summer season silages are a better option of roughage for animal nutrition, mainly when ensiled with dried and pelleted citrus pulp.
}

Key Words: digestibility, Lactobacillus buchneri, Lactobacillus plantarum, pelleted citrus pulp, wilting 


\section{Introdução}

O potencial do Brasil em explorar produtos de origem animal seria mais expressivo caso a exploração pecuária atendesse às limitações desencadeadas pela sazonalidade da produção de volumosos. No verão, as condições climáticas favorecem a síntese de biomassa, mas a maior disponibilidade de água, luz e temperatura promove a conversão de fotoassimilados em tecidos estruturais, reduzindo a digestibilidade da forragem (Machado et al., 1998). No inverno, com a escassez de alimento, é necessária a conservação da forragem excedente produzida no verão.

As espécies a serem ensiladas devem apresentar produtividade e valor nutritivo, como a Brachiaria brizantha cv. Marandu. Entretanto, no momento do corte, esta gramínea apresenta baixos teores de CHO e MS. Portanto, são necessários aditivos que forneçam substratos fermentescíveis e tenham capacidade de absorção da umidade, como é o caso de polpa cítrica. Ao ensilarem o capimmarandu com 24\% de MS, Bergamaschine et al. (2006) verificaram que a inclusão de PCP ou o emurchecimento elevaram os teor de MS e reduziram a proteólise, mas não melhoraram o valor nutritivo das silagens. Segundo Jaster (1995), o emurchecimento reduz o teor de umidade, o que limitaria o crescimento de bactérias e a extensão da fermentação. Contudo, o maior tempo de exposição da forragem eleva as perdas no recolhimento e prejudica o processo de compactação.

O efeito dos inoculantes bacterianos diminui quando o substrato é limitante. Ao compilar trabalhos sobre a inoculação de bactérias láticas em gramíneas tropicais, Sollenberg et al. (2003) verificaram respostas positivas associadas ao alto teor de carboidratos solúveis.

A importância das bactérias homoláticas em converter monossacarídeos em ácido lático e reduzir as perdas fermentativas é comprovada (McDonald et al., 1991). Contudo, estas silagens são mais instáveis em aerobiose, uma vez que o ácido lático não tem ação antimicótica efetiva. Portanto, a redução de perdas em aerobiose é prioridade em pesquisas para avaliação de bactérias heteroláticas, entre elas, o L. buchneri, que tem ação antifúngica efetiva e não compromete a conservação de nutrientes (Ranjit \& kung Jr., 2000).

$\mathrm{Na}$ tentativa de conciliar produção de matéria seca satisfatória, sem que isso resulte em grandes perdas de valor nutritivo, objetivou-se avaliar como o emurchecimento e o uso de PCP e de inoculantes bacterianos afetam o valor nutritivo de silagens de capimmarandu.

\section{Material e Métodos}

As determinações de campo e análises laboratoriais foram realizadas no Departamento de Zootecnia, USP/ ESALQ, em Piracicaba, SP. As atividades na área experimental tiveram início em maio de 2002 e se encerraram em fevereiro de 2003. O capim-marandu foi estabelecido em janeiro de 2001 na forma de plantio direto. Após análise química do solo, realizada em 2002, foi aplicado calcário dolomítico (2.000 kg/ha). Para reposição dos nutrientes, foram aplicados nitrogênio e potássio (200 e $30 \mathrm{~kg} / \mathrm{ha}$, respectivamente). O adubo utilizado foi o Ajifer II, apresentado na forma líquida, com garantia de $12 \%$ de matéria orgânica por tonelada do produto, fabricado pela Ajinomoto Interamericana ${ }^{\circledR}$.

As colheitas foram realizadas com colhedora de forragem da marca Casale ${ }^{\circledR}$, modelo CF 2000 Super de $2 \mathrm{~m}$ largura em julho de 2002 (silagem de inverno) e fevereiro de 2003 (silagem de verão). Este equipamento teve seu conjunto de facas afiado e o de contra-facas aproximado visando à redução do tamanho de partículas do capimmarandu.

No momento da ensilagem, a forragem foi colhida com idades de rebrotação de 70 dias no inverno e 49 dias no verão. A colheita mais tardia, no inverno, foi justificada pelo baixo acúmulo de forragem neste período. Além disso, pretendeu-se reproduzir situação comumente observada pelos produtores, que prorrogam o momento da colheita visando maior acúmulo de forragem. A silagem nãoemurchecida foi composta da forragem colhida com teor de umidade original e foi utilizada também nas silagens com PCP, cuja participação correspondeu a 7,5\% da forragem fresca, para ambas as estações.

Para o emurchecimento da forragem, a janela de manutenção do equipamento foi mantida aberta. Com o corte realizado pelo conjunto de facas móveis do rotor, a forragem foi lançada no campo, onde permaneceu exposta por 5 horas. O capim-marandu desidratado foi, então, recolhido pelo equipamento e submetido à picagem final pelas facas do rotor da máquina.

A inoculação bacteriana foi realizada em 12 das 18 silagens avaliadas. O inoculante contendo bactérias homoláticas (L. plantarum) empregado foi o ECOSIL ${ }^{\circledR}$ Silage Inoculant, da empresa ECOSYL. A fonte de bactérias heteroláticas foi representada pelo inoculante contendo L. buchneri (cepa NCIMB 40788) produzido pela Biotal ${ }^{\circledR}$ (Cardiff, UK). As doses e as formas de aplicação de $L$. plantarum e L. buchneri seguiram as recomendações técnicas dos fabricantes: $1,0 \times 10^{5}$ e 3,6 × $10^{5}$ ufc (unidade 
formadora de colônias) viáveis/g de forragem fresca, respectivamente. A aspersão dos inoculantes foi realizada com pulverizador manual de $500 \mathrm{~mL}$.

Depois de submetido aos tratamentos, o capim-marandu foi acondicionado em baldes de plástico de $20 \mathrm{~L}$, providos de tampa. Após 90 dias do fechamento, os silos experimentais foram abertos e as amostras de silagem foram coletadas para determinação do valor nutritivo.

Amostras de capim-marandu, obtidas no momento da ensilagem, e de suas respectivas silagens foram mantidas em estufa de ventilação forçada $\left(55^{\circ} \mathrm{C}\right)$, durante 72 horas, para determinação do teor de MS (Silva, 1981). Depois de pesadas, as amostras foram trituradas em moinho tipo Willey provido de peneira com orifícios de $1 \mathrm{~mm}$ de diâmetro. Para remoção da água residual, realizou-se a determinação laboratorial da MS (AOAC, 1990). Amostras também foram submetidas a determinação dos teores de CHO (Dubois et al., 1956). As leituras foram realizadas em Colorímetro-Elisa Reader, calibrado para absorbância de $490 \mathrm{~nm}$. O teor de PB foi determinado em auto-analisador de nitrogênio da marca LECO $^{\circledR}$, modelo FP-528 (Leco Corporation, Michigan, USA).

Os teores de FDN e FDA (Tabela 1) foram obtidos pelo método seqüencial proposto pela ANKOM ${ }^{\circledR}$ Fiber Analyser (ANKOM Technology Corporation, Fairport, NY) e descrito por Holden (1999), com adição de sulfito de sódio. O mesmo protocolo foi utilizado na obtenção da DVIVMS.

O delineamento foi o inteiramente casualizado, disposto em arranjo fatorial $2 \times 3 \times 3$, com duas estação do ano, três teores de MS e ausência ou presença de inoculantes bacterianos. Nesse arranjo foram gerados 18 tratamentos, cada um com quatro repetições, perfazendo 72 silos experimentais (unidades experimentais). As variáveis foram analisadas pelo procedimento GLM do programa estatístico SAS ${ }^{\circledR}$, versão 8.02 para Windows ${ }^{\circledR}$ (SAS, 2001). Para efeito

Tabela 1 - Valor nutritivo do capim-marandu no momento da ensilagem

\begin{tabular}{lrc}
\hline Variável $^{1}$ & \multicolumn{2}{c}{ Estação do ano } \\
\cline { 2 - 3 } & Verão & Inverno \\
\hline Matéria seca, \% & 22,8 & 57,7 \\
Cinzas, \% MS & 6,9 & 6,4 \\
Proteína bruta, \% MS & 9,4 & 4,5 \\
FDN, \% MS & 68,4 & 75,7 \\
FDA, \% MS & 42,1 & 49,8 \\
Hemicelulose, \% MS & 26,3 & 25,9 \\
Celulose, \% MS & 38,1 & 42,1 \\
Lignina, \% MS & 4,0 & 7,7 \\
DVIVMS, \% MS & 60,6 & 44,1 \\
\hline
\end{tabular}

${ }_{1}$ FDN = fibra em detergente neutro; FDA = fibra em detergente ácido; DVIVMS = digestibilidade verdadeira in vitro da matéria seca. de comparação de médias entre tratamentos, utilizou-se o teste de média dos mínimos quadrados (LS MEANS) com nível de significância de 5\%.

\section{Resultados e Discussão}

Os teores médios de MS (Tabela 2) variaram de 20,4\% (silagem proveniente do capim não-emurchecido, inoculado com $L$. buchneri, no verão) a $85,4 \%$ (silagem produzida com capim emurchecido, inoculado com $L$. buchneri, no inverno).

O emurchecimento foi uma técnica eficiente em elevar o teor de MS das silagens. Em comparação às silagens de capim não-emurchecido, os teores de MS do capim emurchecido aumentaram $97 \%$ no verão e $51 \%$ no inverno.

A elevada perda de umidade do capim-marandu foi favorecida pelas características climáticas nos dias em que foi realizado o emurchecimento (elevada radiação solar e baixa umidade relativa do ar). Resultados semelhantes foram verificados por Bergamaschine et al. (2006) para a mesma espécie forrageira submetida a emurchecimento durante 4 horas de exposição ao sol. Esta prática foi apontada pelos autores como a mais efetiva em elevar o teor médio de MS das silagens, que aumentou de 24 para $48 \%$.

A adição de 7,5\% de PCP propiciou o aumento do teor de MS das silagens produzidas no verão, o que não foi observado nas silagens produzidas no inverno. Apesar de a diferença ter sido de 3,7 unidades percentuais, este fato não era esperado, pois o teor de MS da PCP é superior ao da forragem, que, no inverno, apresentou teor de MS superior a $50 \%$.

O desdobramento da interação teor de umidade $\times$ estação demonstrou que o teor médio de MS das silagens produzidas no inverno (64,3\%) foi muito superior àquele observado nas silagens de verão (28,6\%). A diferença de $124 \%$ sugere a participação de outros fatores, mais importantes que a estação do ano em influenciar os resultados.

A colheita da forragem em estádio de crescimento mais avançado no inverno (70 dias) favoreceu o aumento do teor de MS, entretanto, ao ensilarem os capins tanzânia e mombaça, Coan et al. (2005) verificaram alterações bem menores no teor médio de MS (de 24,9\% para 26,5\%) quando aumentaram o intervalo de corte de 45 para 60 dias, respectivamente.

A avaliação do regime pluviométrico durante o crescimento do capim-marandu no inverno comprovou déficit hídrico no solo e na forragem, o que provavelmente determinou aumento do conteúdo de colmo (não avaliado), que, ao senescer, poderia perder umidade mais intensamente e aumentar o teor de MS nas silagens de inverno. 
Entre as características morfológicas do capim-marandu, destacou-se a quantidade considerável de material senescente na região basal da planta, que apresentou alto teor de MS. A menor produção de biomassa no inverno contribuiu, portanto, para o aumento da participação de material senescente em comparação às demais frações colhidas, o que elevou o teor de MS.

A amplitude de variação para os teores médios de cinzas das silagens (Tabela 2) foi representada pela silagem proveniente de capim emurchecido e inoculada com $L$. plantarum $(5,7 \%)$ e por aquela de capim nãoemurchecido inoculada com L. buchneri (8,2\%), ambas produzidas no inverno.

Os teores médios de cinzas das silagens, em ambas as estações, foram 10,4\% superiores aos do capim-marandu no momento da ensilagem (6,7\%). O aumento do teor de cinzas das silagens provavelmente está relacionado à perda de matéria orgânica, decorrente dos processos de fermentação e oxidação (McDonald et al., 1991).

Nas silagens de verão e inverno, os teores médios de PB foram, respectivamente, de 8,1 e 4,6\% (Tabela 3). Euclides (1995) também observou maiores teores de PB nas folhas e nos colmos dos capins marandu e tanzânia no período das águas em comparação ao período seco. Os resultados deste experimento apenas se assemelharam aos observados por Euclides (1995), em virtude da maior idade de rebrotação do capim colhido no inverno. Caso a idade de colheita, em ambas as estações, tivesse coincidido com a idade cronológica, provavelmente os maiores teores de PB seriam observados nas silagens produzidas no inverno. Ao avaliarem o valor nutritivo de três gramíneas forrageiras colhidas aos 35 dias de crescimento vegetativo,

Tabela 2 - Teores de matéria seca e cinzas das silagens de capim-marandu

\begin{tabular}{|c|c|c|}
\hline Capim-marandu & MS, \% & Cinzas, \% MS \\
\hline & \multicolumn{2}{|c|}{ Verão } \\
\hline Não-emurchecido & $20,7 \mathrm{cB}(0,5)$ & $7,8 \mathrm{~A} \quad(0,1)$ \\
\hline Emurchecido & $40,7 \mathrm{aB}(0,5)$ & $7,8 \mathrm{~A} \quad(0,1)$ \\
\hline Com polpa cítrica & $24,5 \mathrm{bB}(0,5)$ & $7,8 \mathrm{~A} \quad(0,1)$ \\
\hline \multirow[t]{2}{*}{ Média } & $28,6 \quad(0,3)$ & $(0,06)$ \\
\hline & \multicolumn{2}{|c|}{ Inverno } \\
\hline Não-emurchecido & $56,0 \mathrm{bA}(0,5)$ & $7,8 \mathrm{aA}(0,1)$ \\
\hline Emurchecido & $84,7 \mathrm{a} A(0,5)$ & $5,9 \mathrm{cB}(0,1)$ \\
\hline Polpa cítrica & 52,3 с $A(0,5)$ & $7,4 \mathrm{bB}(0,1)$ \\
\hline Média & 64,3 & $(0,06)$ \\
\hline
\end{tabular}

Valores entre parênteses indicam erro-padrão da média (EPM).

Médias na coluna seguidas de mesmas letras maiúsculas em diferentes estações não diferem entre si $(P>0,05)$.

Médias na coluna seguidas de mesmas letras minúsculas nas mesmas estações não diferem entre si $(P>0,05)$
Gerdes et al. (2000) verificaram maiores teores de PB das gramíneas colhidas no inverno.

Uma vez que o capim foi colhido mais tardiamente no inverno (70 dias), a maturidade pode ter contribuído para reduzir a participação de folhas e aumentar a participação de material senescente, o que poderia explicar a redução dos teores de $\mathrm{PB}$ e de outros componentes potencialmente digestíveis. Segundo Corsi et al. (1994), são necessários 30 a 35 dias para o capim-marandu completar seu ciclo vegetativo.

As silagens contendo PCP preservaram o conteúdo de PB do capim em ambas as estações. Do mesmo modo, ao adicionarem PCP ao capim-tanzânia no momento da ensilagem, Aguiar et al. (2001) verificaram maior preservação do teor de PB nas silagens acrescidas deste aditivo.

O desdobramento da interação teor de umidade $x$ inoculação comprovou que o inoculante contendo L. plantarum preservou a fração nitrogenada somente na silagem de inverno acrescida de PCP. No entanto, a diferença percentual para esta variável foi de apenas 0,4\% (teores de PB de 5,0 e 5,4\% para as silagens controle e com inoculante, respectivamente). $\mathrm{O}$ mesmo inoculante reduziu os teores de $\mathrm{PB}$ das silagens de verão com capim emurchecido (em 0,3\%) ou acrescidas de PCP (em 0,5\%). A não alteração dos teores de PB nas demais silagens e as pequenas diferenças ocasionadas por estas alterações demonstraram que os inoculantes não melhoraram a qualidade das silagens.

Os resultados relacionados aos teores de FDN das silagens (Tabela 4) variaram de 57,9\% (silagem com PCP, não inoculada, no verão) a 81,2\% (silagem emurchecida, não inoculada, no inverno) e encontram-se dentro da ampli-

Tabela 3 - Teores de proteína bruta (\% MS) das silagens de capim-marandu

\begin{tabular}{|c|c|c|}
\hline \multirow[t]{2}{*}{ Capim-marandu } & \multicolumn{2}{|c|}{ Estação do ano } \\
\hline & Verão & Inverno \\
\hline Controle (não-emurchecido) & 7,7 eA $\quad(0,1)$ & $4,5 \mathrm{~dB} \quad(0,1)$ \\
\hline Controle + L. buchneri & 7,9 cde $A(0,1)$ & $4,7 \mathrm{cdB}(0,1)$ \\
\hline Controle + L. plantarum & 8,0 cdeA $(0,1)$ & $4,6 \mathrm{~dB} \quad(0,1)$ \\
\hline Emurchecido & $8,2 \mathrm{bA} \quad(0,1)$ & 3,9 eB $(0,1)$ \\
\hline Emurchecido + L. buchneri & 8,1 bcdA $(0,1)$ & 3,9 eB $\quad(0,1)$ \\
\hline Emurchecido + L. plantarum & $7,8 \mathrm{eA} \quad(0,1)$ & 3,9 eB $(0,1)$ \\
\hline Com polpa cítrica & $8,7 \mathrm{aA} \quad(0,1)$ & 5,0 bсB $(0,1)$ \\
\hline $\begin{array}{l}\text { Com polpa cítrica }+ \\
\text { L. buchneri }\end{array}$ & 8,1 bcA $(0,1)$ & $5,3 \operatorname{abB}(0,1)$ \\
\hline $\begin{array}{l}\text { Com polpa cítrica }+ \\
\text { L. plantarum }\end{array}$ & $8,2 \mathrm{bA} \quad(0,1)$ & $5,4 \mathrm{aB} \quad(0,1)$ \\
\hline Média & $(0,03)$ & $(0,03)$ \\
\hline
\end{tabular}

Valores entre parênteses indicam erro-padrão da média (EPM).

Médias na linha seguidas de mesmas letras maiúsculas não diferem entre si $(P>0,05)$.

Médias na coluna seguidas de mesmas letras minúsculas não diferem entre si $(P>0,05)$. 
tude de variação observada em gramíneas do gênero Panicum. Segundo Euclides (1995), teores de parede celular inferiores a 55\% são raros. Em rebrotas, são comuns teores superiores a $65 \%$ e em estádios mais avançados de maturação, teores de 75 a 80\%.

Os teores médios de FDN das silagens de inverno e verão foram, respectivamente, de 74,0 e 65,7\%. Esse comportamento estacional diferiu do verificado por Mari (2003), que, ao ensilar essa espécie nas mesmas estações observou menores teores de FDN nas silagens de inverno. Esses resultados também diferem da proposta preconizada por Buxton \& Fales (1994) de que as reações responsáveis pela síntese de constituintes da parede celular são promovidas por enzimas e que a elevação da temperatura é condicionante na concentração de vários precursores enzimáticos.

Os altos teores de FDN das silagens de inverno provavelmente foram ocasionados pela interação de vários fatores, entre eles, a colheita da forragem em estádio mais avançado, o que determinou maior lignificação da parede celular e aumento da participação de material senescente na composição da silagem.

Os inoculantes contendo L. plantarum ou L. buchneri não foram efetivos em reduzir os teores médios de FDN das silagens de capim não-emurchecido ou emurchecido, em ambas as estações. Estes teores poderiam ter sido reduzidos caso os inoculantes tivessem propiciado a preservação de compostos solúveis, o que reduziria a participação percentual da parede celular. De acordo com Van Soest (1994), alterações na fração fibrosa são observadas, normalmente, quando cepas de microrganismos estão associadas a enzimas fibrolíticas, embora a ausência de resposta, mesmo na presença destas biocatalisadoras, seja comumente observada.

Contrariando os demais tratamentos, nas silagens de verão acrescidas de PCP, os teores de FDN aumentaram na presença dos dois inoculantes. Situação oposta foi observada no inverno, visto que a silagem acrescida de PCP e inoculada com $L$. plantarum apresentou teor de FDN $(62,4 \%)$ inferior ao da silagem não inoculada $(70,4 \%)$ ou inoculada com L. buchneri $(68,4 \%)$, as quais não diferiram entre si. Esses resultados foram semelhantes aos reportados por Kung Jr. \& Ranjit (2001) de que silagens inoculadas com diferentes cepas de bactérias láticas e enzimas apresentaram teor de FDN inferior ao daquelas não inoculadas. Entretanto, a ausência de enzimas fibrolíticas nos inoculantes utilizados neste experimento torna difícil a explicação da redução do teor de FDN pela ação microbiana.

Os tratamentos contendo PCP foram eficientes em reduzir a participação dos componentes da parede celular das silagens no verão e inverno. A PCP apresenta baixo teor de FDN (23\%), o que contribui para redução desta fração quando adicionada à forragem (Van Soest, 1994). Comportamento semelhante foi verificado por Crestana et al. (2001) ao adicionarem PCP na ensilagem do capim-tanzânia.

A PCP é rica em pectina, polissacarídeo que estruturalmente faz parte da parede celular, porém, do ponto de vista biológico, representa o conteúdo celular. Portanto, seus principais constituintes, galactose e arabinose, que se encontram indisponíveis às bactérias ácido-láticas no início do processo fermentativo, podem se tornar substratos fermentescíveis, como resultado da hidrólise desencadeada pela ação de enzimas da planta adicionadas no momento da ensilagem ou ainda pela hidrólise ácida (McDonald et al., 1994). Este fato, que será abordado mais profundamente na fração HEMI, explica a redução dos teores de FDN das silagens acrescidas de PCP neste experimento.

A prática do emurchecimento propiciou, em ambas as estações, aumento no teor de FDN das silagens, o que foi acompanhado de redução nos teores de CHO (Tabela 5). Provavelmente, as perdas bioquímicas durante a respiração

Tabela 4 - Teores de fibra em detergente neutro (\% MS) das silagens de capim-marandu

\begin{tabular}{|c|c|c|}
\hline \multirow[t]{2}{*}{ Capim-marandu } & \multicolumn{2}{|c|}{ Estação do ano } \\
\hline & Verão & Inverno \\
\hline Não-emurchecido & $66,9 \mathrm{bB} \quad(0,8)$ & $74,3 \mathrm{bA} \quad(0,8)$ \\
\hline Não-emurchecido $+L$. plantarum & $66,8 \mathrm{bB} \quad(0,8)$ & $74,2 \mathrm{bA} \quad(0,8)$ \\
\hline Emurchecido & 69,3 ав $\quad(0,8)$ & $81,2 \mathrm{aA} \quad(0,8)$ \\
\hline Emurchecido + L. buchneri & 69,3 ав $\quad(0,8)$ & 79,9 a A $(0,8)$ \\
\hline Com polpa cítrica + L. buchneri & $61,8 \mathrm{cB} \quad(0,8)$ & $68,4 \mathrm{cA} \quad(0,8)$ \\
\hline Com polpa cítrica $+L$. plantarum & 62,5 c A $\quad(0,8)$ & $62,4 \mathrm{dA} \quad(0,8)$ \\
\hline Média & $(0,3)$ & 74,0 \\
\hline
\end{tabular}

Valores entre parênteses indicam erro-padrão da média (EPM).

Médias na linha seguidas de mesmas letras maiúsculas não diferem $(P>0,05)$ entre si.

Médias na coluna seguidas de mesmas letras minúsculas não diferem $(P>0,05)$ entre si. 
celular, de frações potencialmente digestíveis, resultaram na maior participação percentual da fração FDN. Este resultado diverge do obtido por Vilela et al. (2001), visto que o emurchecimento do capim-elefante por 12 horas propiciou a redução do teor de FDN.

Nas demais frações fibrosas, não foram verificadas interações, portanto, foram avaliadas quanto ao efeito do teor de umidade (Tabela 6). Os teores de FDA em ambas as estações tiveram comportamento semelhante aos de FDN (47,9 e 38,7\% para as silagens de inverno e verão, respectivamente). Este comportamento estacional difere da proposta preconizada por Buxton \& Fales (1994).

A maior idade de rebrotação do capim-marandu, associada à presença de material senescente na colheita de inverno, determinou maior teor de FDA das silagens. Coan et al. (2005) também observaram aumento dos teores médios de FDA em silagens de capim tanzânia e mombaça à medida que o intervalo de cortes aumentou de 45 (44,5\%) para 60 $(48,2 \%)$ dias.

O emurchecimento não alterou o teor médio de FDA das silagens, apesar de ter aumentado seu valor em 2,5 unidades percentuais. Este resultado corrobora os descritos por Bergamaschine et al. (2006), que não observaram efeito do emurchecimento sobre a fração FDA de silagens de capimmarandu emurchecidas (42,7\%) e controle (42,3\%).

Apesar de não terem diferido, os teores médios de FDA das silagens acrescidas de PCP (42,1\%) foram inferiores aos observados na silagem controle (43,3\%), o que pode estar relacionado à menor participação da fração FDA na composição da PCP, que poderia ter promovido efeito significativo de diluição desta variável caso a participação percentual da PCP acrescida à forragem tivesse sido maior. Crestana et al . (2001) também verificaram redução desta variável ao adicionarem PCP às silagens de capim-tanzânia. O teor de FDA foi reduziu de 42,5\% (0\% de PCP) para 39,7\% e 39,0\%, respectivamente, na presença de $5 \%$ e $10 \%$ de PCP na forragem fresca.

Tabela 5 - Teores de carboidratos solúveis (\% MS) das silagens de capim-marandu

\begin{tabular}{|c|c|c|}
\hline \multirow[t]{2}{*}{ Capim-marandu } & \multicolumn{2}{|c|}{ Estação do ano } \\
\hline & Verão & Inverno \\
\hline Não-emurchecido & 1,51a $(0,22)$ & $1,00 \mathrm{~b} \quad(0,22)$ \\
\hline Emurchecido & $0,54 b \quad(0,22)$ & $0,21 \mathrm{c} \quad(0,22)$ \\
\hline Com polpa cítrica & $2,03 \mathrm{aB}(0,22)$ & 3,07 a $\mathrm{A}(0,22)$ \\
\hline Média & $1,36 \quad(0,10)$ & $1,42 \quad(0,10)$ \\
\hline
\end{tabular}

Valores entre parênteses indicam erro-padrão da média (EPM).

Médias na linha seguidas de mesmas letras maiúsculas não diferem $(P>0,05)$ entre si.

Médias na coluna seguidas de mesmas letras minúsculas não diferem $(P>0,05)$ entre si.
Não houve efeito da inoculação bacteriana sobre a fração FDA. Bergamaschine et al. (2006) obtiveram resultados semelhantes ao avaliarem os efeitos de inoculantes contendo bactérias láticas e enzimas fibrolíticas. De acordo com Van Soest (1994), as frações LIG e celulose (CELU) se mantêm estáveis durante a fermentação no interior do silo e são degradadas somente na presença de fungos. Portanto, inoculantes bacterianos não poderiam alterar significativamente os teores de carboidratos estruturais (celulose) e, muito menos, compostos fenólicos (lignina).

Os teores de HEMI variaram de 18,8\% (silagem de inverno, com PCP e L. plantarum) a 31,2\% (silagem de verão, emurchecida e inoculada com $L$. buchneri), valores que corroboram a amplitude de variação de 10 a 30\% sugerida para gramíneas (McDonald et al., 1991). Houve apenas efeito do teor de umidade, uma vez que as silagens produzidas no inverno $(25,4 \%)$ e verão $(26,5 \%)$ apresentaram valores de HEMI semelhantes. Ao ensilar o capim-marandu nas mesmas estações do ano e com diferentes idades de rebrotação, Mari (2003) não observou diferença para esta variável.

A inclusão da PCP reduziu os teores médios de HEMI das silagens para $22,1 \%$, enquanto aquelas de capimmarandu emurchecido ou não-emurchecido apresentaram teores de 29,8 e 27,8\%, respectivamente, e não diferiram entre si. Bernardes et al. (2005) e Crestana et al. (2001) também constataram que a inclusão de PCP ao capimmarandu e capim-tanzânia, respectivamente, no momento da ensilagem, contribuiu para obtenção de menores teores de HEMI das silagens.

A redução dos teores de HEMI das silagens acrescidas de PCP poderia ser explicada pela contribuição deste aditivo em disponibilizar pectina, um polissacarídeo ramificado que aumenta a capacidade fermentativa do material ensilado. Como descrito anteriormente, a pectina é constituída de açúcares, entre eles, a arabinose. Esta pentose, em anaerobiose, na presença de bactérias ácido-láticas homo ou heretofermentativas, produzem os ácidos lático e acético. Estes ácidos orgânicos são reconhecidos por sua capacidade em promover hidrólise ácida, o que pode explicar a redução dos teores de HEMI do material ensilado (McDonald et al., 1991).

A maior capacidade fermentativa na presença da PCP pode ter propiciado maior síntese de hemicelulase pelas bactérias, outra forma de explicar o decréscimo dos teores de HEMI das silagens acrescidas de PCP. Neste caso, somente a análise dos teores de CHO do material a ser ensilado, no momento da ensilagem, poderá subestimar a quantidade de substratos fermentescíveis disponível, pois 
Tabela 6 - Teores das frações fibrosas das silagens de capim-marandu

\begin{tabular}{|c|c|c|c|c|}
\hline & FDA & HEMI & CEL & LIG \\
\hline Não-emurchecido & $42,8 \mathrm{ab}(1,0)$ & $27,8 \mathrm{a} \quad(0,9)$ & $38,2 \mathrm{ab}(0,6)$ & $5,8 \mathrm{~b} \quad(0,1)$ \\
\hline Com polpa cítrica & $41,8 b \quad(1,0)$ & $22,1 b \quad(0,9)$ & $36,9 b \quad(0,6)$ & $5,9 b \quad(0,1)$ \\
\hline
\end{tabular}

Valores entre parênteses indicam erro-padrão da média (EPM).

Médias na coluna seguidas de mesmas letras minúsculas não diferem $(P>0,05)$ entre si.

assim que o material é ensilado, as hemicelulases epifíticas e, na seqüência, a hidrólise ácida, disponibilizam xilose e arabinose aos microrganismos, o que não é evidenciado quando o teor de CHO é mensurado no momento da ensilagem.

A prática do emurchecimento não alterou os teores de HEMI das silagens. Ao submeterem o capim-tifton 85 ao emurchecimento durante duas horas, Reis et al. (2003) também não verificaram alteração dessas frações em silagens emurchecidas (35,8\%) ou controle (34,8\%). É provável que o tempo de exposição da forragem não foi suficiente para induzir a atuação de hemicelulases, responsáveis pela hidrólise desta fração.

Coan et al. (2005) não observaram efeito da inoculação enzimático-bacteriana sobre os teores de HEMI de silagens de capim-tanzânia ou mombaça. Os teores médios de CELU das silagens (Tabela 6) com diferentes teores de umidade variaram de 30,6\% (silagem com PCP, não inoculada, no verão) a 43,3\% (silagem emurchecida, inoculada com L. buchneri, no inverno). Esses valores foram próximos da amplitude de 20 a 40 (\% MS), descrita por Reis \& Jobim (2001) como os teores comumente observados em plantas superiores.

A fração CELU apresentou comportamento semelhante ao das frações FDN e FDA. Os teores médios de CELU das silagens de inverno (40,7\%) foram maiores que os observados nas silagens de verão $(35,6 \%)$. Caso as forragens que originaram as silagens tivessem sido colhidas com a mesma idade cronológica, as silagens de inverno poderiam apresentar menores teores de CELU. Ao avaliar a mesma espécie forrageira colhida em mesma idade cronológica, Mari (2003) verificou maiores teores de CELU nas silagens de verão $(33,1 \%)$ em comparação àquelas confeccionadas no inverno (27,0\%), fato explicado pelas condições climáticas a que as espécies forrageiras foram submetidas no verão. O aumento da temperatura, o fotoperíodo e a disponibilidade de água sinalizam à matriz extracelular a necessidade de converter células do tipo parênquima (rica em conteúdo celular) em células do tipo esclerênquima (rica em parede celular) visando dar suporte estrutural à planta. Assim, ocorre aumento da relação colmo:folha, o que resulta em maior participação dos carboidratos estruturais, entre eles CELU.

As silagens acrescidas de PCP apresentaram menores teores de CELU (36,9\%), embora não tenham diferido das silagens de capim não-emurchecido (38,2\%). Bernardes et al. (2005) verificaram em PCP teor de 21,5\% de CELU. Considerando que a participação percentual de PCP neste trabalho foi de apenas $7,5 \%$, o pequeno decréscimo do teor médio de CELU (1,3\%) era previsível.

As silagens de capim emurchecido (39,3\%) não diferiram daquelas produzidas com capim não-emurchecido (38,2\%) quanto ao teor médio de CELU. Esses resultados não corroboram a proposta de Levitt (1980), uma vez que a perda de água decorrente do emurchecimento determinaria aumento da concentração de ácido abcísico, responsável pelo fechamento dos estômatos e pela elevação da concentração de etileno na planta, que induziria a síntese de celulase e propiciaria a redução dos teores de CELU.

A inoculação das silagens com $L$. plantarum ou L. buchneri não foi efetiva em alterar o teor de CELU. Resultados semelhantes foram observados por Coan et al. (2005) ao ensilarem capins do gênero Panicum com (35,6\%) ou sem (29,5\%) inoculante enzimático-bacteriano. Segundo Van Soest (1994), a CELU se mantém relativamente estável quando submetida ao processo fermentativo, fato constatado também por Reis \& Jobim (2001), que observaram pequena fração de CELU (menos de 5\%) degradada pela ação das enzimas em silagens de gramíneas.

Os teores de LIG variaram de 3,8\% (silagem de capim não-emurchecido e não inoculada, no verão) a 8,5\% (silagem de capim emurchecido e não inoculada, no inverno). As silagens de inverno (7,9\%) apresentaram teor médio de LIG $88,0 \%$ superior ao observado nas silagens de verão $(4,2 \%)$, provavelmente porque as silagens de verão foram produzidas com forragem mais jovem (49 dias de rebrotação) e com menor percentual de material senescente, que apresenta alto teor de LIG.

Ao ensilar a mesma espécie forrageira, Mari (2003) não constatou diferença do teor médio de LIG para as silagens de inverno $(4,1 \%)$ e verão $(4,0 \%)$. Entretanto, verificou maior acúmulo de LIG nas silagens de verão à medida que 
a idade de rebrotação aumentou de 45 (3,3\%) para 60 (4,0\%) e $90 \operatorname{dias}(6,1 \%)$.

Conforme esperado, a inoculação bacteriana não alterou os teores de LIG das silagens. Segundo Van Soest (1994), as frações LIG e CELU se mantêm estáveis durante a fermentação no interior do silo e são degradadas somente na presença de fungos.

As silagens de capim emurchecido apresentaram o maior teor médio de LIG (6,3\%) e diferiram daquelas com capim não-emurchecido (5,8\%) ou acrescidas de PCP (5,9\%). As silagens de capim emurchecido apresentaram menor teor médio de $\mathrm{CHO}$ (Tabela 5), o que pode ter sido resultado das perdas bioquímicas desencadeadas pelo processo de respiração celular. O consumo de compostos solúveis, apesar de pequeno, pode ter sido responsável pelo maior teor de LIG das silagens emurchecidas em 0,5\%.

Os coeficientes de DVIVMS (Tabela 7) das silagens variaram de 40,3\% (silagem de capim emurchecido e não inoculada, no inverno) a 62,1\% (silagem com PCP e não inoculada, no verão).

As silagens de verão apresentaram coeficiente médio de DVIVMS de $56,1 \%$, valor $29,6 \%$ superior ao das silagens de inverno (43,3\%). Este resultado contraria o preconizado na literatura, apesar de compreensível, visto que as silagens de verão apresentaram menores teores médios de FDN, FDA, CELU e LIG e maiores teores de PB. O coeficiente de DVIVMS é reflexo das frações digestíveis (PB e CHO) e potencialmente digestíveis (FDN, FDA, HEMI e CELU). Os efeitos da maturidade da forragem e da participação percentual de material senescente na composição das silagens foram mais importantes que a estação do ano na definição da DVIVMS.

As práticas adotadas para elevar os teores de MS das silagens, em ambas as estações, propiciaram valores nutritivos distintos. A adição de PCP elevou o coeficiente de DVIVMS das silagens (52,9\%), provavelmente por reduzir as frações fibrosas, pela preservação de PB, em decorrência da menor proteólise pelo maior fornecimento de $\mathrm{CHO}$ (Tabela 5), por se tratar de uma fonte de pectina, substrato de alta digestibilidade. Ao adicionarem 5\% de PCP ao capim-tifton 85 no momento da ensilagem, Reis et al. (2003) também observaram aumento da digestibilidade das silagens.

O emurchecimento do capim-marandu durante 5 horas, por sua vez, resultou em silagens com coeficiente médio de DVIVMS de 47,7\%, que não diferiu do coeficiente médio DVIVMS das silagens de capim não-emurchecido (48,6\%). Ao submeter o capim-elefante à mesma técnica durante 6 horas, Vilela et al. (2001) constataram tendência de redução do coeficiente de DVIVMS, o que só ocorreu quando o
Tabela 7 - Digestibilidade verdadeira in vitro da matéria seca (\% MS) das silagens de capim-marandu

\begin{tabular}{lc}
\hline Silagem de capim-marandu & DVIVMS \\
\hline Não-emurchecido & $48,6 \mathrm{~b}(0,4)$ \\
Emurchecido & $47,7 \mathrm{~b}(0,4)$ \\
Com polpa cítrica & $52,9 \mathrm{a}(0,4)$ \\
Média & $49,7(0,2)$
\end{tabular}

Valores entre parênteses indicam erro-padrão da média (EPM).

Médias na coluna seguidas de mesmas letras minúsculas não diferem entre si $(P>0,05)$.

tempo de exposição da forragem foi aumentado para 12 horas.

A inoculação bacteriana como efeito isolado não alterou os coeficientes de DVIVMS das silagens não inoculadas ou inoculadas com L. plantarum ou L. buchneri. Este resultado reforça a afirmação de que estas bactérias acido-láticas contêm pequena ou nenhuma capacidade de degradar componentes da parede celular da planta, o que foi comprovado e discutido anteriormente. Ao ensilarem capins do gênero Panicum com duas idades de rebrotação (45 e 60 dias), na presença ou ausência de inoculante enzimático-bacteriana, Coan et al. (2001) não encontraram diferença no coeficiente de DVIVMS das silagens inoculadas (54,5\%) e testemunha (53,8\%).

A avaliação do valor nutritivo das silagens de capimmarandu comprovou que o capim colhido em maior idade de rebrotação, no inverno, apresentou baixo valor nutritivo, assim como suas silagens. Portanto, forragens colhidas com maior idade de rebrotação resultam em silagens com menores coeficientes de DVIVMS. A perda de valor nutritivo não é compensada pelo aumento significativo da produção de biomassa, o que diminui a produção de MS digestível por hectare.

Os coeficientes de DVIVMS de silagens confeccionadas no verão podem ser considerados aceitáveis e se enquadram nos valores reportados na literatura. Portanto, essas silagens podem ser utilizadas em rações, principalmente se acrescidas de PCP.

\section{Conclusões}

A confecção de silagens de capim-marandu no inverno deve ser analisada de maneira criteriosa.

A menor produtividade de MS, decorrente das limitações climáticas da estação, deve ser compensada pelo valor nutritivo da forragem, que não pode ser colhida tardiamente.

Por ter aumentado as operações no campo e não ter melhorado o valor nutritivo das silagens, o emurchecimento não é indicado. 
O monitoramento especial do tempo de exposição do capim-marandu ao sol é necessário, pois a exposição durante 5 horas resultou em elevada perda de umidade.

A polpa cítrica destacou-se como o melhor tratamento e pode ser indicada como aditivo na produção de silagens, no entanto, a quantidade a ser utilizada deve ser calculada com base na disponibilidade, no custo e nos benefícios em melhorar o valor nutritivo da silagem.

\section{Literatura Citada}

AGUiAR, R.N.S.; CRESTANA, R.F.; BALSALOBRE, M.A.A. et al. Efeito do tamanho de partícula na composição da fração nitrogenada de silagem de capim Tanzânia. In: REUNIÃO ANUAL DA SOCIEDADE BRASILEIRA DE ZOOTECNIA, 38., 2001, Piracicaba. Anais... Piracicaba: Fundação de Estudos Agrários Luiz de Queiroz, 2001. p.314-315.

ASSOCIATION OF OFFICIAL AGRICULTURAL CHEMISTS. Official methods of analysis. 15.ed. Arlington: AOAC International, 1990. 1117p.

BERGAMASCHINE, A.F.; PASSIPIÉRI, M.; VERIANO FILHO, W.V. et al. Qualidade e valor nutritivo de silagens de capimMarandu (B. brizantha cv. Marandu) produzidas com aditivos ou forragem emurchecida. Revista Brasileira de Zootecnia, v.35, n.4, p.1454-1462, 2006.

BERNARDES, T.F.; REIS, R.A.; MOREIRA, A.L. Fermentative and microbiological profile of Marandu-grass ensiled with citrus pulp pellets. Scientia Agrícola, v.62, n.3, p.214-220, 2005.

BUXTON, D.R.; FALES, S.L. Plant environment and quality. In: FAHEY JR., G.C.; COLLINS, M.; MERTENS, D.R. et al. (Eds.). Forage quality, evaluation and utilization. Madison: ASA; SSSA, 1994. p.155-159.

COAN, R.M.; VIEIRA, P.F.; SILVEIRA, R.N. et al. Inoculante enzimático-bacteriano, composição química e parâmetros fermentativos das silagens dos capins Tanzânia e Mombaça. Revista Brasileira de Zootecnia, v.34, n.2, p.416-424, 2005. CORSI, M.; BALSALOBRE, M.A.; SANTOS, P.M. et al. Bases para o estabelecimento do manejo de pastagens de braquiária. In: SIMPÓSIO SOBRE MANEJO DA PASTAGEM, 11., 1994, Piracicaba. Anais... Piracicaba: Fundação de Estudos Agrários Luiz de Queiroz, 1994. p.249-266.

CRESTANA, R.F.; AGUIAR, R.N.S.; BALSALOBRE, M.A.A. et al. Efeito da fermentação na fração fibra de silagens de capim Tanzânia. In: REUNIÃO ANUAL DA SOCIEDADE BRASILEIRA DE ZOOTECNIA, 38., 2001, Piracicaba. Anais... Piracicaba: Sociedade Brasileira de Zootecnia, 2001. p.354-355.

DUBOIS, M.; GILLES, K.A.; HAMILTON, J.K. et al. Colorimetric method for determination of sugars and related substances. Analytical Chemistry, v.28, p.350-356, 1956.

EUCLIDES, V.P.B. Valor alimentício de espécies forrageiras do gênero Panicum. In: SIMPÓSIO SOBRE MANEJO DA PASTAGEM, 12., 1995, Piracicaba. Anais... Piracicaba: Fundação de Estudos Agrários Luiz de Queiroz, 1995. p.245-273.

GERDES, L.; WERNER, J.C.; COLOZZA, M.T. et al. Avaliação de características de valor nutritivo das gramíneas forrageiras
Marandu, Setária e Tanzânia nas estações do ano. Revista Brasileira de Zootecnia, v.29, n.4, p.955-963, 2000.

HOLDEN, L.A. Comparison of methods of in vitro dry matter digestibility for ten feeds. Journal of Dairy Science, Lancaster, v.82, n.8, p.1791-1794, 1999.

JASTER, E.H. Legume and grass silage preservation. In: MOORE, K.J.; KRAL, D.M.; VINEY, M.K. (Eds.) Post harvest physiology and preservation of forage. Madison: CSSA, ASAS, CSSA, p.91-115, 1995. (Special Publication, 22).

KUNG JR., L.; RANJIT, N.K. The effect of Lactobacillus buchner and other additives on the fermentation and aerobic stability of barley silage. Journal of Dairy Science, v.84, p.11491155, 2001.

LEVITT, J. Responses of the plants to environmental stress. New York: Academic Press, 1980. 324p.

MACHADO, A.O.; CECATO, U.; MIRA, R.T. Avaliação da composição química e digestibilidade in vitro da matéria seca de cultivares e acessos de Panicum maximum Jacq. sob duas alturas de corte. Revista Brasileira de Zootecnia, v.27, n.5, p.1057-1063, 1998.

MARI, L.J. Intervalo entre cortes em capim-marandu (Brachiaria brizantha (Hochts. ex A. Rich.) Stapf cv. Marandu): produção, valor nutritivo e perdas associadas à fermentação da silagem. Piracicaba: Escola Superior de Agricultura Luiz de Queiroz, 2003. 138p. Dissertação (Mestrado em Agronomia) Escola Superior de Agricultura Luiz de Queiroz, 2003.

McDONALD, P.; HENDERSON, A.R.; HERON, S.J.E. The biochemistry of silage. 2.ed. Mallow: Chalcombe Publications, 1991. 340p.

RANJIT, N.K.; KUNG JR., L. The effects of Lactobacillus buchneri, Lactobacillus plantarum, or a chemical preservative on the fermentation and aerobic stability of corn silage. Journal of Dairy Science, v.83, n.3, p.526-535, 2000.

REIS, R.A.; COAN, R.M.; BERNARDES, T.F. et al. Valor nutritivo do capim Tifton 85 ensilado com diferentes conteúdos de umidade. In: REUNIÃO ANUAL DA SOCIEDADE BRASILEIRA DE ZOOTECNIA, 40., 2003, Santa Maria. Anais... Santa Maria: Sociedade Brasileira de Zootecnia/Gmosis [2003] (CD-ROM).

REIS, R.A.; JOBIM, C.C. Perfil da fração de carboidratos da planta e adequação de aditivos no processo de ensilagem. In: WORKSHOP SOBRE MILHO PARA SILAGEM, 2., 2000, Piracicaba. Anais... Piracicaba: Fundação de Estudos Agrários Luiz de Queiroz, 2001. p.27-51.

STATISTICAL ANALYSIS SYSTEM - SAS. The SAS System for Windows: version 8.02. Cary: SAS Institute, 2001. (CD-ROM).

SILVA, D.J. Análise de alimentos: métodos químicos e biológicos. Viçosa, MG: Unversidade Federal de Viçosa, 1981. 166p.

SOLLENBERGER, L.E.; REIS, R.A.; NUSSIO, L.G. et al. Conserved forage. In: MOSER, L.E.; BURSON, B.L.; SOLLENBERGER, L.E. (Eds.) Warm aeason grasses. Madison: American Society of Agronomy, Crop Science Society of America, Soil Science Society of America, 2004. p.355-387.

Van SOEST, P.J. Nutritional ecology of the ruminant. 2.ed. New York: Cornell University Press, 1994. 476p.

VILELA, H.; BARBOSA, F.A.; DIAS, E.T. et al. Qualidade das silagens de capim-elefante Paraíso (Pennisetum hybridum cv. Paraíso) submetidas a três tempos de emurchecimento. In: REUNIÃO ANUAL DA SOCIEDADE BRASILEIRA DE ZOOTECNIA, 38., 2001, Piracicaba. Anais... Piracicaba: Sociedade Brasileira de Zootecnia, 2001. p.323-324. 